ISSN 1392-3196 / e-ISSN 2335-8947

Zemdirbyste-Agriculture, vol. 103, No. 1 (2016), p. 99-106

DOI 10.13080/z-a.2016.103.013

\title{
Responses of pea plants to heat stress and spermine treatment
}

\author{
Dessislava TODOROVA ${ }^{1}$, Zornitsa KATEROVA ${ }^{1}$, Elena SHOPOVA ${ }^{1}$, \\ Milda JODINSKIENE ${ }^{2}$, Sigita JURKONIENE ${ }^{2}$, Iskren SERGIEV ${ }^{1}$ \\ ${ }^{1}$ Institute of Plant Physiology and Genetics, Bulgarian Academy of Sciences \\ Acad. G. Bonchev 21, 1113 Sofia, Bulgaria \\ E-mail: dessita@bio21.bas.bg \\ ${ }^{2}$ Institute of Botany, Nature Research Centre \\ Akademijos 2, 08412 Vilnius, Lithuania
}

\begin{abstract}
The effects of high temperature and the polyamine spermine on the physiological and biochemical status of garden pea plants were investigated. The plants were preliminary treated with $1 \mathrm{mM}$ spermine and $24 \mathrm{~h}$ later were subjected for $48 \mathrm{~h}$ to conditions with daily temperature up to $38^{\circ} \mathrm{C}$. High temperature stress caused more than $20 \%$ decrease of leaf pigments content and significant suppression of net photosynthesis rate. An enhanced level of lipid peroxidation was observed in leaves suggesting that oxidative stress occurred. A decrease in the content of free proline, total phenolics, and hydrogen peroxide accompanied by an increase of the activity of catalase, superoxide dismutase, and guaiacol peroxidase was established in plants subjected to high temperature. The harmful physiological effects of high temperature were alleviated by spraying the plants with spermine. The preliminary application of spermine retarded leaf pigment loss and maintained photosynthetic rate and antioxidant enzyme activities, as well as content of non-enzymatic antioxidants.
\end{abstract}

Key words: antioxidant enzymes, high temperature stress, photosynthesis, Pisum sativum, polyamine, stress markers.

\section{Introduction}

The elevated air temperature is one of the major abiotic stress factors related to the global climate changes (Wahid et al., 2007). Heat stress influences principal physiological and biochemical processes and thus affects the overall plant growth and productivity. Under heat stress conditions, an accumulation of reactive oxygen species (ROS) occurs and free radicals damage plant biomembranes (Wahid et al., 2007). To cope with the unfavourable environmental conditions plants have developed a complex of antioxidant defense systems, which include non-enzymatic and enzymatic antioxidants. The plants are capable of coping with the oxidative stress by activation of some or all of these systems (Gill, Tuteja, 2010 a). The endogenous plant defence system can be strengthened by application of plant growth regulating substances. Polyamines are organic compounds with straight $\mathrm{C}_{3}-\mathrm{C}_{15}$ aliphatic structure bearing at least two primary amino groups and one or more internal imino groups. Polyamines participate in a number of important developmental processes in plants. Because of their polycationic nature, polyamines possess free radical scavenging features and antioxidantactivity. They stabilize the negatively charged macromolecules and may confer plant tolerance to different biotic and abiotic stresses

(Groppa, Benavides, 2008; Gill, Tuteja 2010 b). The application of polyamines decreased electrolyte leakage and malondialdehyde from different tissue sections of soybean seedlings subjected to high temperature (HT) stress, suggesting protection of membrane integrity (Amooaghaie, Moghym, 2011). Exogenous spermidine noticeably enhanced the activities of antioxidant enzymes superoxide dismutase, ascorbate peroxidase, and catalase in HT-treated cucumber seedlings (Tian et al., 2012). The authors concluded that foliar spray with spermidine effectively improved the total antioxidant capacity of cucumber seedlings, which enhanced plant tolerance. Pre-treatment of soybean seedlings with putrescine, spermine and spermidine at $28^{\circ} \mathrm{C}$ for $2 \mathrm{~h}$ prior to heatshock $\left(45^{\circ} \mathrm{C}\right.$ for $\left.2 \mathrm{~h}\right)$, enhanced the recovery growth of roots and hypocotyls (Amooaghaie, Moghym, 2011). It is believed that spermine ( $\mathrm{Spm})$ possesses the highest protective role toward unfavourable conditions because of its highest positive charge due to its four amine groups (Bouchereau et al., 1999).

Pea is a traditionally cultivated spring crop in Bulgaria. High yield, shorter vegetation period and early ripening characterize garden pea variety 'Ran-1'. Elevated temperatures $\left(>30^{\circ} \mathrm{C}\right)$ during pea flowering 
period can cause blossom shedding. Rapid temperature changes have become be a frequent phenomenon in the region recently, and the search for quick solutions to environmental stress problems is important. This study is an attempt to evaluate the protective role of the polyamine spermine against high temperature stress.

\section{Materials and methods}

Plant material and treatments. Garden pea (Pisum sativum L., var. 'Ran-1') plants were grown as a water culture under controlled growth conditions (12/12 $\mathrm{h}$ photoperiod, $150 \mu \mathrm{mol} \mathrm{m} \mathrm{m}^{-2} \mathrm{~s}^{-1}$ photon flux density, $24 / 22^{\circ} \mathrm{C}$ day/night temperatures, air humidity about $80 \%$ ) during April 2013 and May 2014. Twenty-one-days old plants (3-4 leaf stage) were divided into two groups:
1) control - non-treated and 2) spermine (Spm)-treated (1 mM). Tween $80(0.01 \%)$ was used as a surfactant. Twenty-four hours after Spm treatment, half of the control and Spm-treated plants were subjected to high temperature (HT) for 2 days. During each day of the HT-stress program the temperature was progressively elevated from $22^{\circ} \mathrm{C}$ to $38^{\circ} \mathrm{C}(9: 00$ a.m. to $12: 00$ a.m.), and was kept till 17:00 p.m., after that it was decreased to $22^{\circ} \mathrm{C}$. The air humidity was up to $50 \%$. After the end of the stress program (day 24), the plants were transferred to initial growth conditions for 4 days to recover. The physiological responses of plants were determined $24 \mathrm{~h}$ (day 23) and $48 \mathrm{~h}$ (day 24) of the HT-stress program, and $24 \mathrm{~h}$ (day 25) and $96 \mathrm{~h}$ (day 28) of the recovery period (Fig. 1).

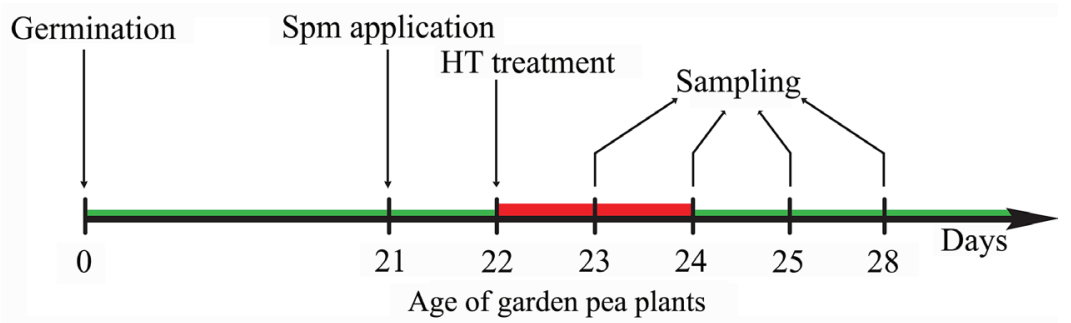

Note. High temperature (HT) treatment was held during days 22-24, and during days 24-28 the plants were transferred to initial growth conditions for recovery.

Figure 1. Scheme of treatment

Biochemical analyses. Selected parameters such as photosynthesis rate, contents of leaf photosynthetic pigments, free proline, free thiol-containing compounds, malondialdehyde, total phenols, and hydrogen peroxide as well as the activities of catalase, guaiacol peroxidase, and superoxide dismutase were measured in the $3^{\text {rd }}$ leaf pair. Plant material was collected from 3-5 plants and composite samples were used for biochemical analyses. Photosynthetic pigments were extracted with $80 \%$ acetone from two leaf discs ( $8 \mathrm{~mm}$ diameter) and determined according to the method of Arnon (1949). Net photosynthesis rate was determined by a portable photosynthesis measuring system LCPro+ (ADC, UK). Fresh leaf material (approximately 300 $\mathrm{mg}$ ) was homogenized with $0.1 \%(\mathrm{w} / \mathrm{v})$ trichloroacetic acid for determination of free proline, soluble phenols, free thiol-containing compounds, hydrogen peroxide $\left(\mathrm{H}_{2} \mathrm{O}_{2}\right)$ and malondialdehyde (MDA). Free proline was measured as described by Bates et al. (1973) by using of nynhidryne reagent and absorbance was read at $520 \mathrm{~nm}$. Total phenolics content was determined according to the method of Swain and Goldstein (1964) by using of FolinCiocalteu reagent supplemented with sodium carbonate and absorbance was read at $725 \mathrm{~nm}$. Gallic acid was used as a referent standard. Content of free thiol-containing compounds was determined with Ellman's reagent and absorbance was read at $412 \mathrm{~nm}$ (Edreva, Hadjiiska, 1984). Malondialdehyde content was estimated as a parameter reflecting biomembrane integrity deterioration. It was determined as thiobarbituric acid-reagent product according to Kramer et al. (1991) by using extinction coefficient $155 \mathrm{mM}^{-1} \mathrm{~cm}^{-1}$. Hydrogen peroxide content was estimated spectrophotometrically by the method of Alexieva et al. (2001). The amount of hydrogen peroxide was calculated using a standard curve prepared with known concentrations of $\mathrm{H}_{2} \mathrm{O}_{2}$.

For the assay of antioxidant enzymes, fresh plant material (approximately $200 \mathrm{mg}$ ) was homogenized in $100 \mathrm{mM}$ potassium phosphate buffer ( $\mathrm{pH}$ 7.0) containing $1 \mathrm{mM}$ EDTA and 1\% polyvinylpyrrolidone $(\mathrm{w} / \mathrm{v})$. The homogenates were centrifuged at 12000 $\times \mathrm{g}$ for $15 \mathrm{~min}$. Catalase (CAT, EC 1.11.1.6) activity was measured by following the decomposition of hydrogen peroxide and was determined by monitoring the absorbance decrease at $240 \mathrm{~nm}\left(\varepsilon=36.8 \mathrm{mM}^{-1} \mathrm{~cm}^{-1}\right)$ for $60 \mathrm{~s}$ (Aebi, 1984). Guaiacol peroxidase (POX, EC 1.11.1.7) activity was measured by using of guaiacol as electron donor and the absorbance increase due to the guaiacol oxidation at $470 \mathrm{~nm}\left(\varepsilon=26.6 \mathrm{mM}^{-1} \mathrm{~cm}^{-1}\right)$ was recorded for $60 \mathrm{~s}$ (Dias, Costa, 1983). Total superoxide dismutase (SOD, EC 1.15.1.1) activity was assayed by monitoring the inhibition of photochemical reduction of nitrobluetrazolium (NBT). One unit of SOD activity was defined as the amount of enzyme required to cause $50 \%$ inhibition of the reduction of NBT as monitored at $560 \mathrm{~nm}$ (Beauchamp, Fridovich, 1971).

All spectrophotometrical measurements were made on Multiskan Spectrum (Thermo Electron Corporation, Finland). The kinetic measurements of catalase and guaiacol peroxidase activities were made on spectrophotometer Shumadzu UV-1601 UV-Visible (Shimadzu, Japan). 
Statistical analysis. All experiments were repeated three times with three replicates each. The data reported are mean values \pm SE. The significance of differences was statistically analyzed using Duncan's multiple range test at a level of significance of 0.05 .

\section{Results}

The leaf pigments were decreased significantly only in the HT-treated plants as compared to the respective control. Chlorophyll $a$ was decreased by $13 \%$, and remained lower than the control by $20 \%$ till the end (day 28) of the experimental period (Fig. 2 A). Similar tendency was observed for chlorophyll $b$ content (Fig. 2 B). Carotenoides (Fig. 2 C) were also lessened in HT-treated plants and reached $70 \%$ of the control levels at the end of the recovery period. Spermine increased the leaf pigments content and the values in both Spm-treated variants (alone applied and combined with HT) remained higher then these measured in the control plants. Net photosynthesis rate (Fig. 2 D) was considerably reduced by $39 \%$ after $24 \mathrm{~h}$ of HT treatment, then it maintained relatively stable level but it was significantly lower as compared to control value at the $28^{\text {th }}$ day (4 days of recovery period). However, the Spm application considerably increased net photosynthesis rate starting from day 23 (first day of stress programme) - by 13, 20, 41 and $42 \%$, respectively as compared to control values. When Spm was applied before HT treatment, the net photosynthesis rate initially was decreased by $12 \%$ (day 23 - first day of stress programme), then an increase by $23 \%$ was detected on day 25 (first day of recovery period), which did not change significantly till the end of the experiment (day 28 - fourth day of recovery period).

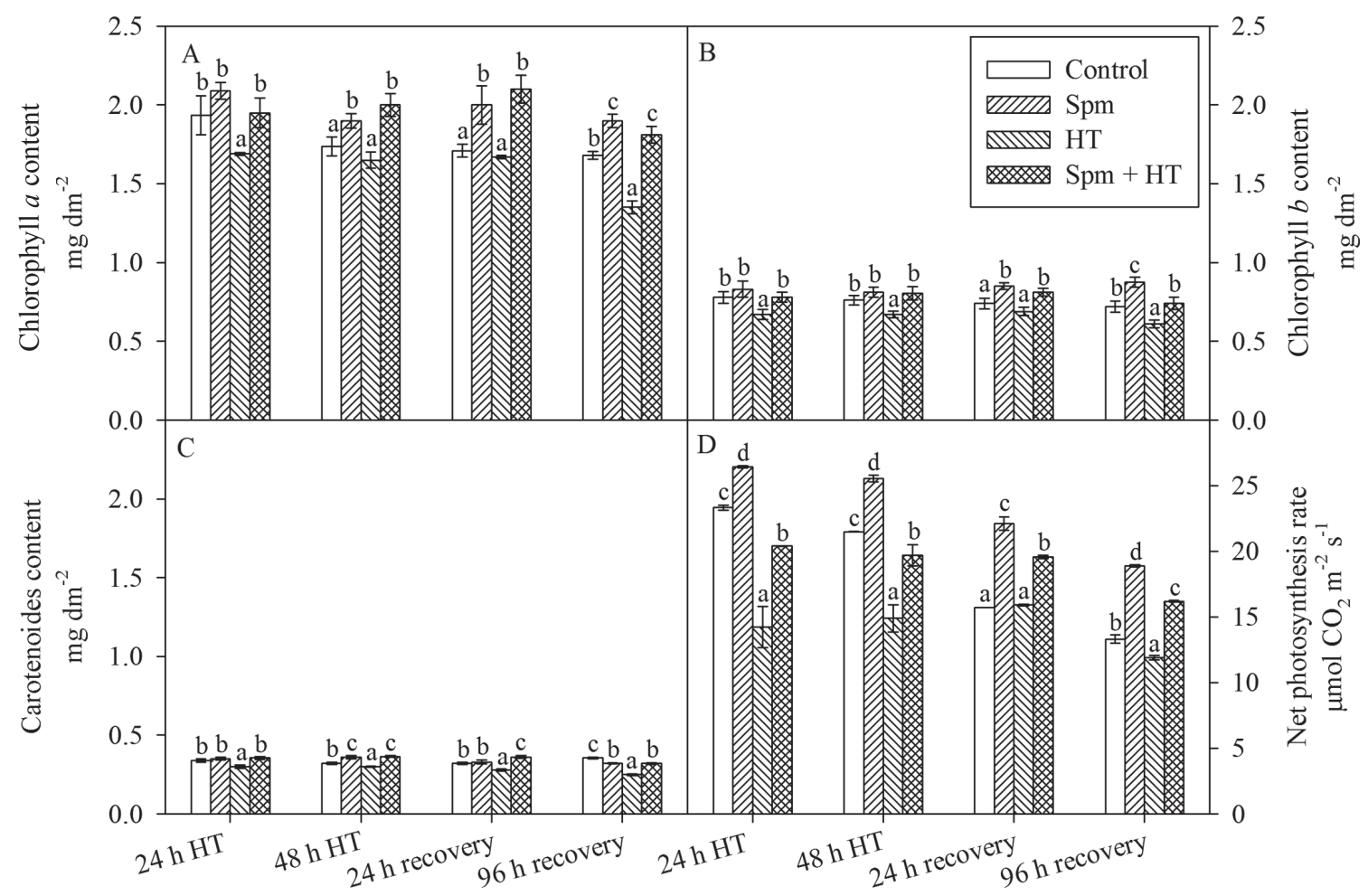

High temperature treatment

Note. Different letters designate statistically significant difference at $p<0.05$.

Figure 2. Chlorophyll $a(\mathrm{~A})$, chlorophyll $b(\mathrm{~B})$ and carotenoides (C) content, and net photosynthesis rate (D) of garden pea plants sprayed with $1 \mathrm{mM}$ spermine (Spm) and subjected to high temperature (HT) treatment for $48 \mathrm{~h}$

MDA content of HT-treated plants was increased by $24 \%$ at day 23 (after first day of stress programme), and remained higher by $20 \%$ than the control (Fig. 3A) at day 28 (fourth day of recovery period). The application of Spm alone did not alter significantly MDA level and it was near the control values during all measurement points. Immediately after HT treatment MDA accumulation was $10 \%$ in Spm + HT-treated plants and remained constant till the end of the recovery period (day 28 ).

An increase of free proline by $18 \%$ was established only after HT treatment at the first measurement point (day 23), then a significant decrease - by $30 \%$ (day 24), 21\% (day 25) and 17\% (day 28) was detected and proline levels remained below the control value (Fig. 3 B). Spermine application caused an enhancement in free thiols content (Fig. 3 C) by $25 \%$ after first day of stress programme (day 23), 34\% after second day of stress programme (day 24) and $51 \%$ at first day of recovery period (day 25), respectively in alone Spmtreated plants and by 13\% (day 23), $30 \%$ (day 24) and $31 \%$ (day 25), respectively in Spm + HT-treated plants as compared to the control values. At the fourth day of 
recovery period (day 28), the levels in Spm-treated and control plants were nearly equal. The content of free thiols in HT-treated plants was $18 \%$ below the control level at fourth day of recovery period ( $28^{\text {th }}$ day).

Initially at day 23 an increase (by 13\%) of phenolics amount was established in HT-treated plants, then the level was decreased by $17 \%$ after second day of stress programme (day 24), $13 \%$ at first day of recovery period (day 25) and 9\% at fourth day of recovery period (day 28) as compared to the respective controls (Fig. 3D). At first, total phenolics amount was raised in plants treated with Spm by $20 \%$ after first day of stress programme (day 23), 10\% after second day of stress programme (day 24) and $30 \%$ at first day of recovery period (day $25)$, respectively. When combined with HT, Spm also enhanced noticeably total phenolics content as compared to HT-treated plants with exception of data obtained on day 23 (after first day of stress programme). At the end of the experiment (fourth day of recovery period - day 28) no differences were established between control, Spmtreated and combine-treated plants.

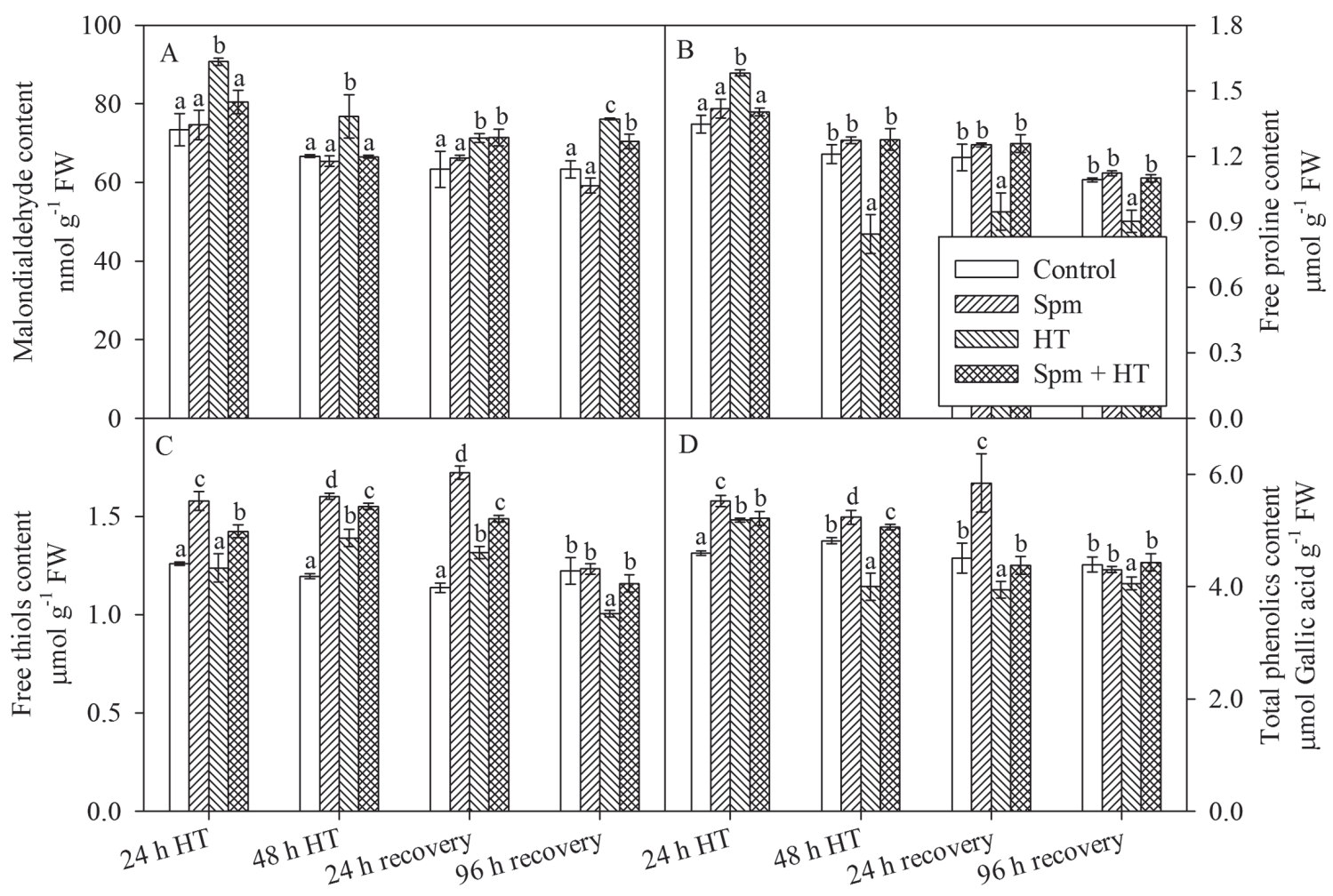

High temperature treatment

Note. Different letters designate statistically significant difference at $p<0.05 ; \mathrm{FW}-$ fresh weight.

Figure 3. Malondialdehyde (A), free proline (B), free thiol-containing compounds (C) and total phenolics (D) content of garden pea plants sprayed with $1 \mathrm{mM}$ spermine $(\mathrm{Spm})$ and subjected to high temperature (HT) treatment for $48 \mathrm{~h}$

Spermine application caused significant increase in $\mathrm{H}_{2} \mathrm{O}_{2}$ level in plants - by $46 \%$ after first day of stress programme (day 23), $51 \%$ after second day of stress programme (day 24), $40 \%$ at first day of recovery period (day 25) and 39\% at fourth day of recovery period (day 28), respectively to the control levels (Fig. 4 A). When combined with HT, Spm treatment resulted in rise of $\mathrm{H}_{2} \mathrm{O}_{2}$ up to $20 \%$ only at the last measurement point (day 28). HT stress led to a decrease in $\mathrm{H}_{2} \mathrm{O}_{2}$ content, especially at the $28^{\text {th }}$ day (by $40 \%$ ) as compared to the respective controls.

SOD activity was enhanced by $30 \%$ after first day of stress programme (day 23), 39\% after second day of stress programme (day 24), 24\% at first day of recovery period (day 25) and $15 \%$ at fourth day of recovery period (day 28), respectively by the alone application of Spm (Fig. 4 B). Initially after first day of stress programme (day 23) the HT treatment led to a decrease in SOD activity by $15 \%$, and then a significant increase was established, which was maintained during the recovery period. The combined treatment did not alter considerably SOD activity. The CAT activity (Fig. 4 C) was enhanced significantly only by the HT treatment and at the end of the recovery period (day 28 ) it reached $51 \%$ above the control.

The application of Spm led to some decrease in POX activity (Fig. 4 D) by $5 \%$ after first (day 23) and second (day 24) days of stress programme, and by $7 \%$ at first day of recovery period (day 25 ) and $9 \%$ at fourth day of recovery period (day 28). High temperature treatment decreased POX activity by $17 \%$ after first day of stress programme (day 23), and then (at day 24) an increase by $24 \%$ was detected. The enzymatic activity of POX in HTtreated only plants remained higher than the respective 


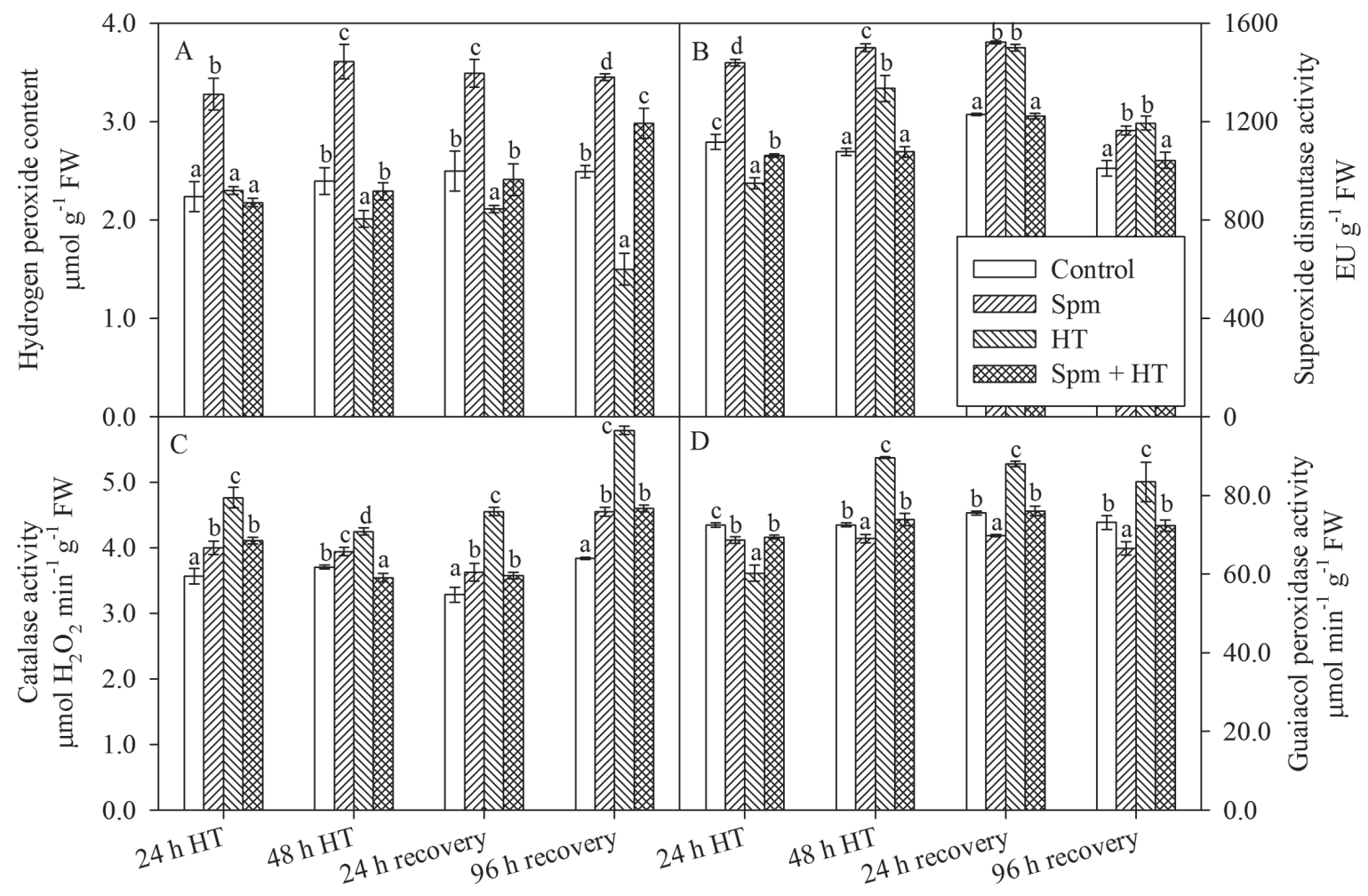

High temperature treatment

Note. Different letters designate statistically significant difference at $p<0.05 ; \mathrm{FW}-$ fresh weight.

Figure 4. Hydrogen peroxide content (A), activity of superoxide dismutase (B), catalase (C) and guaiacol peroxidase (D) of garden pea plants sprayed with $1 \mathrm{mM}$ spermine (Spm) and subjected to high temperature (HT) treatment for $48 \mathrm{~h}$

controls during the recovery period $(17 \%$ at first day of recovery -25 day and $14 \%$ at fourth day of recovery day 28). The POX activity in plants treated with Spm + HT was near to control values after second day of stress programme (day 24) and this trend remained constant during recovery period.

\section{Discussion}

Leaf pigments were slightly increased in Spmtreated plants as compared to the control but Spm treatment considerably enhanced net photosynthesis rate similarly to those results reported by other authors and reviewed by Shu et al. (2012). The leaf pigments declined considerably under HT conditions, suggesting structural damage to the chloroplasts as reported previously (Wahid et al., 2007; Kumar et al., 2012). As a result, the net photosynthesis rate was inhibited (Shu et al., 2012). In Spm + HT-treated plants leaf pigment amount was near the control values during the whole experimental period, which led us to suppose that Spm lessened leaf pigment losses induced by HT. So, we support the assumption proposed by other authors (Stoynova et al., 1999; Hamdani et al., 2011) that under various stresses Spm application protected the photosynthetic apparatus. Further, this reflected on the net photosynthesis rate, which was higher in Spm + HT-treated peas than that measured in HT-treated plants. Our results are in accordance with those reported in other studies that
Spm had a beneficial effect on the net photosynthesis rate in cucumber seedlings grown on excess of $\mathrm{NO}_{3}^{-}$(Wang et al., 2010) and rice seedlings subjected to drought stress (Farooq et al., 2009). We suppose that preliminary application of Spm allowed garden pea plants to adapt easier to HT stress by maintaining net photosynthesis rate to valuable levels.

The temperature stress causes generation of ROS (Gill, Tuteja, 2010 a) which damage cellular biomembranes and as a consequence an accumulation of MDA occurs (Wahid et al., 2007). The increase of MDA concentration found after HT exposure indicates that oxidative damage is taking place in membranes of garden pea plants. However, less MDA enhancement was detected in combined treatment $(\mathrm{Spm}+\mathrm{HT})$. Exogenous Spm decreased the lipid peroxidation under HT stress. This result is in accordance with previous reports where the application of polyamines decreased malondialdehyde in various plant seedlings, suggesting protection of membrane integrity (Amooaghaie, Moghym, 2011; Tian et al., 2012). The fact that MDA amount was lower in plants subjected to combined treatment than in HT-treated plants showed that Spm might assist plants to overcome the negative effect of the temperature stress. In view of the fact that Spm plays an important role in stabilizing the function of cell biomembranes (Groppa, Benavides, 2008; Gill, Tuteja, 2010 b) we also propose that possibly 
Spm was conjugated to membrane phospholipids and stabilized cell constituents. Thus, Spm could diminish the damage of membrane integrity and protect pea against HT stress.

The generation of $\mathrm{H}_{2} \mathrm{O}_{2}$ from the electron transport chains in mitochondria and chloroplasts is a normal physiological process (Gill, Tuteja, 2010 a). Under optimum temperature conditions, the endogenous concentration of $\mathrm{H}_{2} \mathrm{O}_{2}$ depends on the balance between the rate of its production and utilization (mainly by CAT and different peroxidases). SOD catalyzes the dismutation of superoxide anion into oxygen and hydrogen peroxide. Catalase decomposes $\mathrm{H}_{2} \mathrm{O}_{2}$ into water, whereas peroxidases utilize $\mathrm{H}_{2} \mathrm{O}_{2}$ by oxidation of co-substrates such as phenolic compounds and/or antioxidants (Gill, Tuteja, 2010 a). However, under stress conditions, the overproduction of $\mathrm{H}_{2} \mathrm{O}_{2}$ prevails and disturbs a number of metabolic processes. Unexpectedly, we found that $\mathrm{H}_{2} \mathrm{O}_{2}$ content was increased considerably only by Spm when applied alone. The increase of SOD activity by Spm suggested an enhanced production of $\mathrm{H}_{2} \mathrm{O}_{2}$. An evidence exists that the application of polyamines can cause an increase in the activities of antioxidant enzymes which scavenge $\mathrm{H}_{2} \mathrm{O}_{2}$ (Singh, Malik, 2011; Tian et al., 2012; Li et al., 2014). This effectively improved the total antioxidant ability of plants, and an excess of $\mathrm{H}_{2} \mathrm{O}_{2}$ was not observed. However, in our study CAT activity was not increased considerably, and POX activity was even slightly inhibited by Spm application. Another source of $\mathrm{H}_{2} \mathrm{O}_{2}$ is the oxidation of polyamines by di- and polyamine oxidases (Gill, Tuteja, 2010 b) and the observed Spmincreased $\mathrm{H}_{2} \mathrm{O}_{2}$ could be due to substrate-activated polyamine oxidases.

In HT-treated plants, $\mathrm{H}_{2} \mathrm{O}_{2}$ was constantly decreasing during the experimental period. It has to be noted that although SOD activity was enhanced, the activities of the enzymes detoxifying $\mathrm{H}_{2} \mathrm{O}_{2}$ were also steadily increased. An increase in CAT and POX activity is supposed to be an adaptive reaction to prevent the damage by reducing the toxic levels of $\mathrm{H}_{2} \mathrm{O}_{2}$ produced during the cell metabolism and renders protection against oxidative stress provoked by $\mathrm{NaCl}$ (Sudhakar et al., 2001). An increased POX (Liu, Huang, 2000) and CAT (Sairam et al., 2000) activity was reported in a number of plant species under HT stress. Further, an increase in CAT and POX activity is also associated with accelerated scavenging of $\mathrm{H}_{2} \mathrm{O}_{2}$ in HT-treated plants (Liu, Huang, 2000; Sairam et al., 2000; Tian et al., 2012). Although the activities of antioxidant enzymes were mainly increased by HT stress, the exogenous Spm had an attenuating effect on the enzymatic activities measured in Spm + HT-treated plants. Spm pretreatment normalized the level of $\mathrm{H}_{2} \mathrm{O}_{2}$ and the activities of antioxidant enzymes in Spm + HT-treated plants as compared to the HT-treated only plants. This provides evidence that preliminary application of Spm facilitates the adaptation reactions of garden pea plants to HT stress explicated by better physiological and biochemical status.

Glutathione is the most abundant low- molecular thiol-containing compound in living cells, which plays defence roles in ROS detoxification (Gill, Tuteja, $2010 \mathrm{a}$ ). The insufficient increase and further drop of thiol compounds below the control in HT-treated plants may be an indicator for impaired redox state of the cells. Spm application significantly augmented thiol-containing compounds either alone or in combination with HT. The initial increase of free thiol levels by Spm diminished with time and finally reached the corresponding control values. Usually polyamine application leads to increase in antioxidant capacity of plants. For example, Verma and Mishra (2005) reported that exogenous putrescine increased glutathione concentrations, which improved salinity tolerance and adaptation of seedlings of Indian mustard. The higher content of low-molecular thiols in $\mathrm{Spm}+$ HT-treated plants as compared to its quantity in HT-treated, led us to assume that preliminary spraying with Spm provoked an adaptation response.

Plant phenolics and proline are components of the non-enzymatic defense (Gill, Tuteja, 2010 a). Accumulation of plant phenolics under high temperature conditions could be considered as an acclimation mechanism against thermal stress as previously proposed by Rivero et al. (2001). The exact role of proline accumulation in plants is still under discussion but it is thought to play an adaptive and signal role in plant stress tolerance (Szabados, Savouré, 2010). The pretreatment with Spm increased the content of phenolic compounds and proline in Spm + HT-treated plants as compared to the HT-treated only. Thus, we suggest that spraying with Spm has a favourable role for maintaining phenolic compounds and proline in HT-treated plants near the control levels.

\section{Conclusions}

1. Treatment of plants with spermine (Spm) prior to high temperature (HT) stress provoked less decrease in leaf pigment content, net photosynthesis rate, total phenolics content, free proline and thiol-containing compounds as compared to those in plants treated with high temperature only.

2. The activities of antioxidant enzymes in Spm + HT-treated plants were not as much altered as those measured in HT-treated garden pea plants.

3. Exogenous application of spermine could alleviate the harmful physiological effects on garden pea plants provoked by rapid increase of the temperature.

\section{Acknowledgments}

The authors express their gratitude to project DMU 03/60 and to Bulgaria-Lithuania joint research project (2012-2015). The authors sincerely thank Asya Nikolova, Nina Georgieva and Dzhovani Polizoev from the IPPG-BAS for their skilled technical assistance.

Received 22082015

Accepted 20012016 


\section{References}

Aebi H. 1984. Catalase in vitro. Methods of enzymology, 105: $121-126$ http://dx.doi.org/10.1016/S0076-6879(84)05016-3

Alexieva V., Sergiev I., Mapelli S., Karanov E. 2001. The effect of drought and ultraviolet radiation on growth and stress markers in pea and wheat. Plant, Cell and Environment, 24: $1337-1344$ http://dx.doi.org/10.1046/j.1365-3040.2001.00778.x

Amooaghaie R., Moghym S. 2011. Effect of polyamines on thermotolerance and membrane stability of soybean seedling. African Journal of Biotechnology, 10 (47): 9673-9679

Arnon D. I. 1949. Copper enzymes in isolated chloroplasts. Polyphenol oxidase in Beta vulgaris. Plant Physiology, 24: $1-15$ http://dx.doi.org/10.1104/pp.24.1.1

Bates L. S., Waldren R. P., Teare J. D. 1973. Rapid determination for free proline for water stress studies. Plant and Soil, 39: 205-207 http://dx.doi.org/10.1007/BF00018060

Beauchamp C., Fridovich I. 1971. Superoxide dismutase: improved assays and an assay applicable to acrylamide gels. Analytical Biochemistry, 44: 276-287 http://dx.doi.org/10.1016/0003-2697(71)90370-8

Bouchereau A., Aziz A., Larher F., Martin-Tanguy J. 1999. Polyamines and environmental challenges: recent development. Plant Science, 140 (2): 103-125 http://dx.doi.org/10.1016/S0168-9452(98)00218-0

Dias M., Costa M. M. 1983. Effect of low salt concentrations on nitrate reductase and peroxidase of sugar beet leaves. Journal of Experimental Botany, 34: 537-543 http://dx.doi.org/10.1093/jxb/34.5.537

Edreva A., Hadjiiska E. 1984. About the determination of sulfhydril (thiol) group content in plant material. Physiologiya na rasteniyata, 10: 73-82 (in Bulgarian)

Farooq M., Wahid A., Lee D. J. 2009. Exogenously applied polyamines increase drought tolerance of rice by improving leaf water status, photosynthesis and membrane properties. Acta Physiologia Plantarum, 31: 937-945 http://dx.doi.org/10.1007/s11738-009-0307-2

Gill S., Tuteja N. 2010 (a). Reactive oxygen species and antioxidant machinery in abiotic stress tolerance in crop plants. Plant Physiology and Biochemistry, 48: 909-930 http://dx.doi.org/10.1016/j.plaphy.2010.08.016

Gill S., Tuteja N. 2010 (b). Polyamines and abiotic stress tolerance. Plant Signaling and Behavior, 5: 26-33 http://dx.doi.org/10.4161/psb.5.1.10291

Groppa M. D., Benavides M. P. 2008. Polyamines and abiotic stress: recent advances. Amino Acids, 1: 35-45 http://dx.doi.org/10.1007/s00726-007-0501-8

Hamdani S., Gauthier A., Msilini N., Carpentier R. 2011 Positive charges of polyamines protect PSII in isolated thylakoid membranes during photoinhibitory conditions. Plant and Cell Physiology, 52 (5): 866-873 http://dx.doi.org/10.1093/pcp/pcr040

Kramer G., Norman H., Krizek D., Mirecki R. 1991. Influence of UV-B radiation on polyamines, lipid peroxidation and membrane lipids in cucumber. Phytochemistry, 30: 2101-2108 http://dx.doi.org/10.1016/0031-9422(91)83595-C

Kumar S., Gupta D., Nayyar H. 2012. Comparative response of maize and rice genotypes to heat stress: status of oxidative stress and antioxidants. Acta Physiologia Plantarum, 34 (1): 75-86 http://dx.doi.org/10.1007/s11738-011-0806-9
Li Z., Peng Y., Zhang X.-Q., Ma X., Huang L.-K., Yan Y.-H. 2014. Exogenous spermidine improves seed germination of white clover under water stress via involvement in starch metabolism, antioxidant defenses and relevant gene expression. Molecules, 19: 18003-18024 http://dx.doi.org/10.3390/molecules 191118003

Liu X., Huang B. 2000. Heat stress injury in relation to membrane lipid peroxidation in creeping bentgrass. Crop Science, 40: 503-510 http://dx.doi.org/10.2135/cropsci2000.402503x

Rivero R. M., Ruiz J. M., García P. C., López-Lefebre L. R., Sánchez E., Romero L. 2001. Resistance to cold and heat stress: accumulation of phenolic compounds in tomato and watermelon plants. Plant Science, 160 (2): 315-321 http://dx.doi.org/10.1016/S0168-9452(00)00395-2

Sairam R. K., Srivastava G. C., Saxena D. C. 2000. Increased antioxidant activity under elevated temperatures, a mechanism of heat stress tolerance in wheat genotypes. Biologia Plantarum, 43: 245-251 http://dx.doi.org/10.1023/A:1002756311146

Shu S., Guo S.-R., Yuan L.-Y. 2012. A review: polyamines and photosynthesis. Najafpour M. (ed.). Advances in photosynthesis - fundamental aspects, p. 439-464 http://dx.doi.org/10.5772/26875

Singh Y., Malik C. P. 2011. Phenols and their antioxidant activity in Brassica juncea seedlings growing under $\mathrm{HgCl}_{2}$ stress. Journal of Microbiology and Biotechnology Research, 1 (4): $124-130$

Stoynova E. Zh., Karanov E. N., Alexieva V. 1999. Subcellular aspects of the protective effect of spermine against atrazine in pea plants. Plant Growth Regulation, 29: 175-180 http://dx.doi.org/10.1023/A:1006249514986

Sudhakar C., Lakshmi A., Giridarakumar S. 2001. Changes in the antioxidant enzyme efficacy in two high yielding genotypes of mulberry (Morus alba L.) under $\mathrm{NaCl}$ salinity. Plant Science, 161: 613-619 http://dx.doi.org/10.1016/S0168-9452(01)00450-2

Swain T., Goldstein J. L. 1964. The quantitative analyses of phenolic compounds. Pridham J. B. (ed.). Methods in polyphenol chemistry. Oxford, UK, p. 131-146

Szabados L., Savouré A. 2010. Proline: a multifunctional amino acid. Trends in Plant Science, 15 (2): 57-114 http://dx.doi.org/10.1016/j.tplants.2009.11.009

Tian J., Wang L.-P., Yang Y.-J., Sun J., Guo S.-R. 2012. Exogenous spermidine alleviates the oxidative damage in cucumber seedlings subjected to high temperatures. Journal of American Society of Horticultural Science, 137: 11-19

Verma S., Mishra S. N. 2005. Putrescine alleviation of growth in salt stressed Brassica juncea by inducing antioxidative defense system. Journal of Plant Physiology, 162: 669-677 http://dx.doi.org/10.1016/j.jplph.2004.08.008

Wahid A., Gelani S., Ashraf M., Foolad M. R. 2007. Heat tolerance in plants: an overview. Environmental and Experimental Botany, 61: 199-223 http://dx.doi.org/10.1016/j.envexpbot.2007.05.011

Wang X.-H.,Wang X.-F.,Yang F.-J., Wei M., Shi Q.-H., Jiao J., Liu Q.-X. 2010. Effects of exogenous spermine on activities of antioxidant enzymes and photosynthesis in cucumber seedlings under $\mathrm{NO}_{3}^{-}$stress. Plant Nutrition and Fertilizer Science, 16 (4): 1020-1026 
ISSN 1392-3196 / e-ISSN 2335-8947

Zemdirbyste-Agriculture, vol. 103, No. 1 (2016), p. 99-106

DOI 10.13080/z-a.2016.103.013

\title{
Karščio ir apdorojimo sperminu įtaka žirniams
}

\author{
D. Todorova ${ }^{1}$, Z. Katerova ${ }^{1}$, E. Shopova ${ }^{1}$, M. Jodinskienè ${ }^{2}$, S. Jurkoniené2 ${ }^{2}$ I. Sergiev ${ }^{1}$ \\ ${ }^{1}$ Bulgarijos mokslų akademijos Augalų fiziologijos ir genetikos institutas \\ ${ }^{2}$ Gamtos tyrimų centro Botanikos institutas, Lietuva
}

\section{Santrauka}

Tiriant aukštos temperatūros ir poliamino spermino poveiki žirnių fiziologinei bei biocheminei būklei, augalai pirmiausia buvo paveikti $1 \mathrm{mM}$ spermino ir po 24 val. perkelti 48 valandoms i $38^{\circ} \mathrm{C}$ paros temperatūros sąlygas. Dėl aukštos temperatūros streso poveikio lapų pigmentų kiekis sumažejo daugiau nei $20 \%$, o fotosintezès greitis gerokai sulètejo. Paveikus aukšta temperatūra buvo nustatytas padidèjęs augalų lapų lipidų peroksidacijos lygis, rodantis, kad ịvyko oksidacinis stresas. Laisvojo prolino, fenolinių junginių ir vandenilio peroksido kiekio sumažejimas sietinas su katalazès, superoksido dismutazès ir gvajakolio peroksidazès aktyvumo padidejjimu paveikus aukšta temperatūra. Žalingas aukštos temperatūros poveikis augalų fiziologinei būklei buvo sušvelnintas augalus purškiant sperminu. Augalus paveikus sperminu vèl padidėjo prarastas pigmentų kiekis ir fotosintezès greitis, taip pat antioksidacinių fermentų veikla ir nefermentinių antioksidantų kiekis.

Reikšminiai žodžiai: antioksidantiniai fermentai, aukštos temperatūros stresas, fotosintezé, Pisum sativum, poliaminai, streso žymekliai.

Please use the following format when citing the article:

Todorova D., Katerova Z., Shopova E., Jodinskienė M., Jurkonienė S., Sergiev I. 2016. Responses of pea plants to heat stress and spermine treatment. Zemdirbyste-Agriculture, 103 (1): 99-106 DOI 10.13080/z-a.2016.103.013 